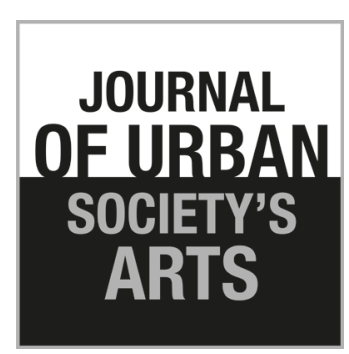

Volume 5 Nomor 2,

Oktober 2018: 59-65

\title{
Pedagogi Estetik Berbasis Kearifan Lokal melalui Kriya Nusantara Batik Cianjur
}

\author{
Wuri Handayani dan Nia Emilda
}

Program Studi Tata Rias Busana, Fakultas Seni Rupa dan Desain

Institut Seni Budaya Indonesia (ISBI) Bandung

Jl. Buah Batu No. 212 Kota Bandung

Tlp. 081318868862, E-mail: wuri08handayani@gmail.com

\begin{abstract}
ABSTRAK
Jawa Barat memiliki keanekaragaman seni dan budaya, salah satunya ialah kriya nusantara berupa batik yang ada di Kabupaten Cianjur. Motif batik Cianjur disesuaikan dengan keadaan alam dan kearifan lokal yang ada dan hal ini menjadi pendukung bagi Kabupaten Cianjur sebagai salah satu destinasi wisata di Jawa Barat. Motif batik Cianjur selain memiliki nilai estetik juga memiliki nilai pendidikan, sehingga bisa dijadikan sebagai media pedagogi estetik bagi masyarakat. Penelitian ini menggunakan pendekatan kualitatif, metode studi kasus, dengan tujuan untuk mendapatkan gambaran komprehensif mengenai proses pedagogi estetik melalui kriya nusantara batik Cianjur.

Kata kunci: pedagogi estetik; kriya nusantara; batik Cianjur
\end{abstract}

\begin{abstract}
Local Wisdom-based Aesthetic Pedagogy through Indonesian Archipelago Craft: Cianjur Batik. West Java is rich of arts and cultural diversity, among others, the Indonesian archipelago craft of batik in Cianjur Regency. The Cianjur batik motif is adapted to prevailing natural condition and local genius that support Cianjur Regency as a tourist-destination in West Java. The Cianjur batik motif has both aesthetic and education values so that it can be used as an aesthetic pedagogy media for society. This study employs qualitative approach and case-study method in order to obtain a comprehensive description of aesthetic pedagogy through the Indonesian archipelago craft of Cianjur batik.
\end{abstract}

Keywords: aesthetic pedagogy; Indonesian archipelago craft; Cianjur batik

\section{Pendahuluan}

Cianjur merupakan salah satu kabupaten di Jawa Barat, berjarak sekitar $65 \mathrm{~km}$ dari pusat ibukota provinsi yang memiliki keanekaragaman produk budaya, salah satunya ialah kriya nusantara batik Cianjur sebagai wujud dari budaya yang memiliki nilai-nilai kearifan lokal bagi masyarakat sebagaimana yang dijelaskan oleh Lopiana Margaretha Panjaitan dan Dadang Sundawa (2016: 65) bahwa "Budaya yang ada di Indonesia mengandung makna kearifan lokal bagi masyarakat di wilayah asal budaya itu dikenal."

Secara etimologi istilah batik berasal dari kata yang berakhiran "tik", berasal dari kata menitik yang berarti menetes yaitu menitikkan malam dengan canting sehingga membentuk corak yang terdiri atas susunan titikan dan garisan (Anas, 2000:14). Batik adalah gambar yang dihasilkan dengan menggunakan alat canting atau sejenisnya dengan bahan lilin sebagai penahan masuknya warna. Batik sebagai kata benda merupakan hasil penggambaran corak di atas kain dengan menggunakan canting sebagai alat gambar dan malam sebagai zat perintang.

Batik Cianjur merupakan wujud budaya dalam bentuk kriya seni yang dimiliki oleh Kabupaten Cianjur dengan aplikasi motif-motif yang sesuai dengan keadaan dan kearifan lokal yang ada. Komarudin Kudiya (2013) juga menjelaskan 
bahwa batik Cianjur merupakan batik khas wilayah Cianjur dengan motif yang menggambarkan potensi alam dan ragam budaya yang kaya makna dan filosofi dalam tradisi setempat.

Batik Cianjur memiliki nilai estetika yang khas dan unik sekaligus juga memiliki nilai pedagogis yang dapat dijadikan sebagai media pendidikan bagi generasi muda dalam mengenal dan melestarikan batik Cianjur sebagai salah satu kriya nusantara yang berharga.

Istilah pedagogi berasal dari bahasa Yunani dari kata paedos dan agogos. Paedos artinya anak, sedangkan agogos artinya membawa atau membimbing. Secara etimologi pedagogi berarti membawa atau membimbing anak. Pada perkembangannya istilah pedagogi diartikan secara luas sebagai proses membimbing anak untuk mencapai tujuan dengan menyelesaikan tugas hidup sebagai tujuan dari tugas pendidikan. Langeveld (Uyoh Sadulloh, 2010) membagi dua istilah yaitu pedagogik dan pedagogi. Pedagogik diartikan dengan ilmu mendidik. Lebih menitikberatkan kepada pemikiran bagaimana membimbing anak, mendidik anak. Sedangkan istilah pedagogi berarti pendidikan, yang lebih menekankan kepada praktik, menyangkut kegiatan mendidik.

Pedagogi dalam artian yang luas merupakan proses pendidikan, yaitu situasi yang disengaja diciptakan untuk memberikan pengaruh pada orang lain dalam rangka mencapai tujuan hidupnya. Dalam penelitian ini istilah yang digunakan ialah pedagogi sebagai praktik, yang melibatkan proses pendidikan dalam konteks estetika.

Jacob Sumardjo (2000) menjelaskan bahwa istilah estetika ditemukan oleh seorang filsuf bernama A.G. Baumgarten pada tahun 1750 yang diambil dari bahasa Yunani Kuno, yaitu dari kata Aistheton, yang berarti kemampuan melihat lewat penginderaan. Selanjutnya ia menambahkan bahwa estetika juga merupakan pengetahuan tentang keindahan alam dan seni. Nilai estetik menempatkan nilai tertingginya pada bentuk keharmonisan. Apabila nilai ini ditilik dari subjek yang memilikinya, maka akan muncul kesan indah dan tidak indah. Pedagogi estetik yang diteliti dalam penelitian ini ialah proses pendidikan yang dilakukan melalui keindahan karya seni khususnya batik Cianjur.
Sewan Susanto (1974) menyatakan bahwa seni batik merupakan keahlian turun temurun yang sejak mulai tumbuh merupakan satu sumber kehidupan yang memberikan lapangan kerja yang cukup luas bagi masyarakat. Seni batik merupakan penyaluran kreasi yang mempunyai arti tersendiri, yang kadang-kadang dihubungkan dengan tradisi, kepercayaan dan sumber-sumber kehidupan yang berkembang di masyarakat.

Batik Cianjur dengan motif yang menggambarkan potensi alam dan ragam budaya yang kaya akan makna menjadi daya tarik bagi pengrajin untuk senantiasa mengembangkan motif batik sehingga bisa digunakan dan dilestarikan oleh masyarakat untuk menjaga eksistensi budaya sebagai bagian dari eksistensi bangsa, sebagaimana yang dikemukakan oleh Agustinus Tampubolon dan Cecep Darmawan (2016: 19) bahwa "Pembangunan eksistensi suatu bangsa akan terjaga melalui kebudayaan yang diciptakan oleh manusia itu sendiri”.

Tujuan Penelitian ini ialah untuk mendapatkan deskripsi komprehensif mengenai: bentuk proses pedagogi estetik melalui batik Cianjur, faktor pendukung dan penghambat, serta upaya yang dilakukan untuk mempertahankan nilai pedagogis dan estetis batik Cianjur.

Penelitian ini menggunakan pendekatan kualitatif dengan metode studi kasus. Pemilihan metode studi kasus dalam penelitian ini dengan pertimbangan bahwa penelitian ini dilakukan dengan seksama terhadap kejadian atau peristiwa, aktivitas, proses yang dilakukan oleh individu ataupun sekelompok orang terkait dengan pelaksanaan pedagogi estetik melalui kriya nusantara batik Cianjur.

Kontribusi dari penelitian ini diharapkan mampu membantu perkembangan ilmu pengetahuan di bidang pendidikan, sosial, seni, dan budaya, serta bisa menjadi pengayaan pada matakuliah yang berkaitan dengan hasil penelitian.

\section{Pembahasan \\ Proses Pedagogi Estetik melalui Batik Cianjur}

Pemerintah Kabupaten Cianjur melalui Keputusan Bupati Cianjur No. 430/Kep.55- 
Kopdaginpar/2013 tentang Penetapan Motif Batik Khas Kabupaten Cianjur yang merupakan wujud kriya yang sarat dengan nilai-nilai luhur yang dimiliki oleh masyarakat Kabupaten Cianjur. Adapun motif batik Cianjur yang ditetapkan ialah motif Galuh Mukti.

Lampiran Keputusan Bupati No. 430/ Kep.55Kopdaginpar/2013 tentang Penetapan Motif Batik Khas Kabupaten Cianjur memuat di antaranya ialah tentang makna motif batik Galuh Mukti khas Cianjur sebagai berikut: 1) bentuk lingkaran merupakan lambang persatuan/ pemerataan dari elemen masyarakat; 2) kubah yang mengarah ke atas, makna/ simbol kepada ke-esa-an Tuhan Maha Pencipta alam semesta; 3) sepasang padi melambangkan kesejahteraan, kemakmuran; 4)

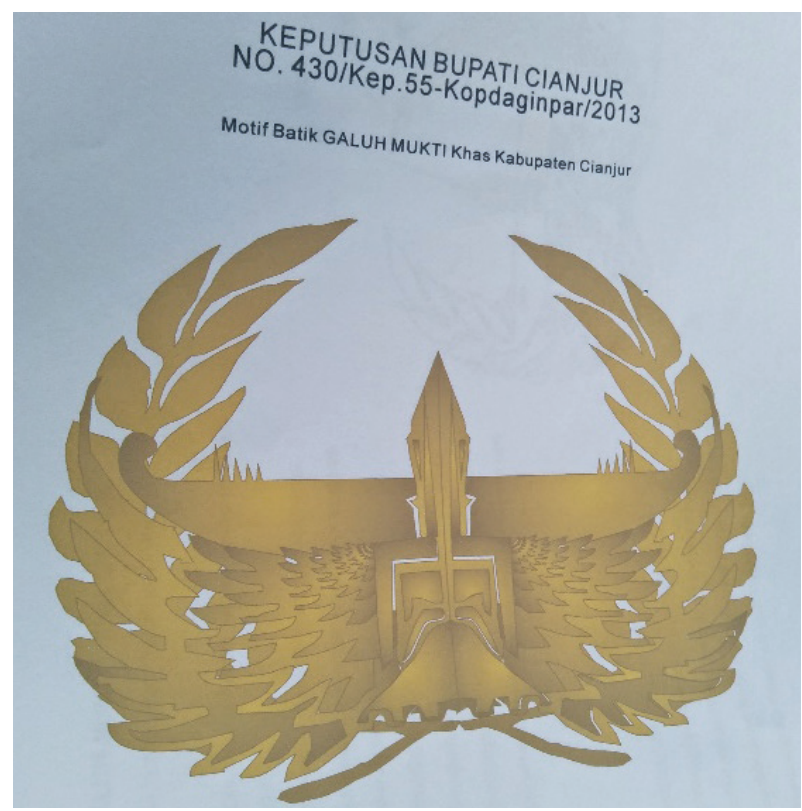

Gambar 1. Motif batik Galuh Mukti khas Kabupaten Cianjur. (Sumber: dokumentasi penelitian, 2018)

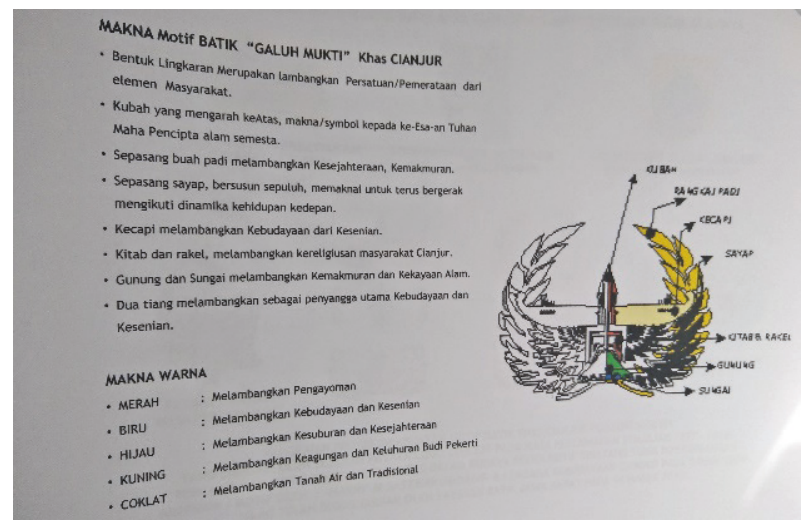

Gambar 2. Lampiran Keputusan Bupati tentang penetapan motif batik khas Kabupaten Cianjur.

(Sumber: dokumentasi penelitian, 2018) sepasang sayap, bersusun sepuluh, memaknai untuk terus bergerak mengikuti dinamika kehidupan ke depan; 5) kecapi melambangakn kebudayaan dari kesenian; 6) kitab dan rakel melambangkan kereligiusan masyarakat Cianjur; 7) gunung dan sungai melambangkan kemakmuran dan kekayaan alam; dan 8) dua tiang melambangkan sebagai penyangga utama kebudayaan dan kesenian.

Makna warna batik Ciajur juga dijelaskan dalam lampiran Keputusan Bupati No. 430/ Kep.55-Kopdaginpar/2013 tentang Penetapan Motif Batik Khas Kabupaten Cianjur sebagai berikut: 1) merah: melambangkan pengayoman; 2) biru: melambangkan kebudayaan dan kesenian; 3) hijau: melambangkan kesuburan dan kesejahteraan; 4) kuning: melambangkan keagungan dan keluhuran budi pekerti; 5) coklat: melambangkan tanah air dan tradisional.

Penjelasan tentang makna motif dan warna batik Cianjur tersebut menunjukkan bahwa batik Cianjur tidak hanya memiliki nilai estetis saja, namun juga mengandung banyak nilai-nilai luhur yang bisa dilakukan melalui proses pedagogi estetik.

Ada beberapa upaya yang dilakukan oleh masyarakat Cianjur dalam proses pedagogi estetik melalui Batik Cianjur, baik upaya yang dilakukan oleh lembaga pendidikan formal, maupun oleh lembaga pendidikan non formal.

1. Pedagogi Estetik melalui Batik Cianjur pada Lembaga Pendidikan Formal

Penggunaan batik Cianjur sebagaimana dijelaskan dalam Surat Edaran Bupati Cianjur No. 025/058/ Organisasi tentang Penggunaan Pakaian Dinas Pegawai Negeri Sipil di Lingkungan Pemerintah Kabupaten Ciabjur pada poin ke 3 menjelaskan bahwa PDH motif batik khas Cianjur digunakan pada hari Kamis. Surat edaran tersebut disambut baik oleh Pegawai Negeri Sipil di lingkungan Pemerintah Kabupaten Cianjur, bahkan himbauan untuk menggunakan batik khas Cianjur juga diterapkan kepada setiap jenjang pendidikan formal yang ada di Kabupaten Cianjur, sehingga himbauan tersebut tidak hanya berlaku untuk guru dan pegawai saja, namun juga berlaku bagi siswa-siswi. 
Proses pedagogi estetik batik Cianjur juga didukung dengan diselenggarakan lomba desain batik Cianjur yang diikuti oleh siswa-siswi tingkat Sekolah Menengah Pertama yang ada di Kabupaten Cianjur, kemudian, desain terbaik dijadikan sebagai motif seragam batik Cianjur bagi siswa-siswi yang ada di Sekolah Menengah Pertama di Kabupaten Cianjur.

2. Pedagogi Estetik melalui Batik Cianjur pada Lembaga Pendidikan Non Formal

Ada beberapa lembaga pendidikan non formal yang fokus terhadap pelatihan batik bagi remaja di Kabupaten Cianjur, salah satunya ialah

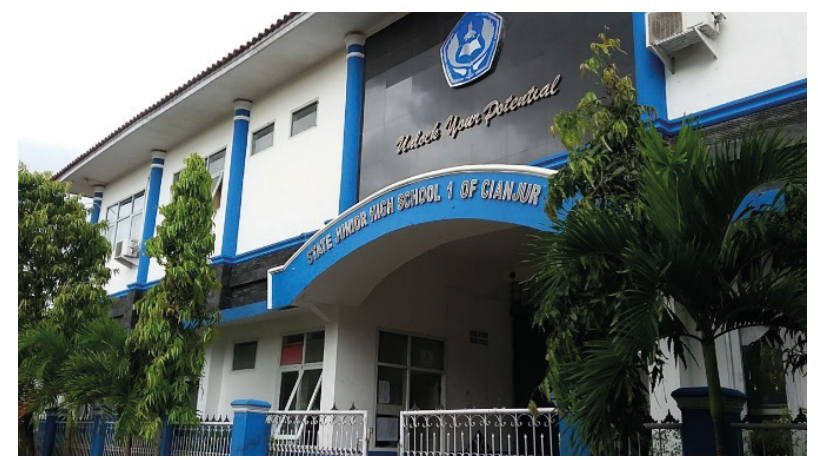

Gambar 3. SMPN 1 Kabupaten Cianjur, salah satu lembaga pendidikan formal yang melestarikan batik Cianjur. (Sumber: dokumentasi penelitian, 2018)

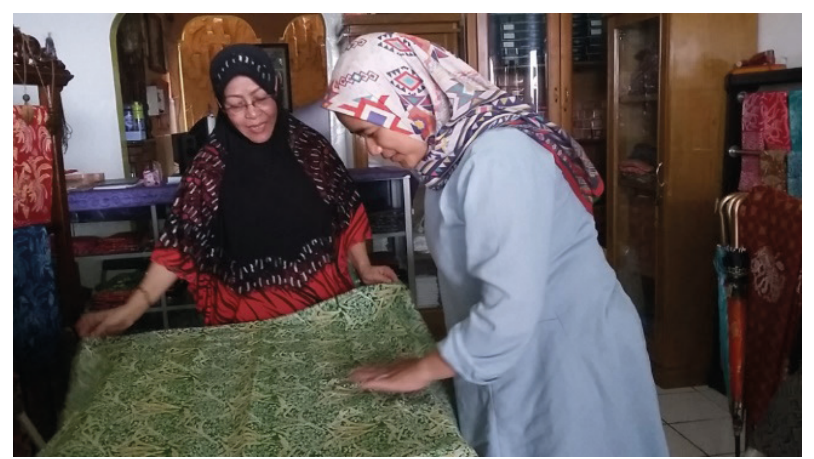

Gambar 4. Pimpinan lembaga pendidikan dan keterampilan sedang menjelaskan tentang motif batik cianjur kepada Peneliti. (Sumber: dokumentasi penelitian, 2018)

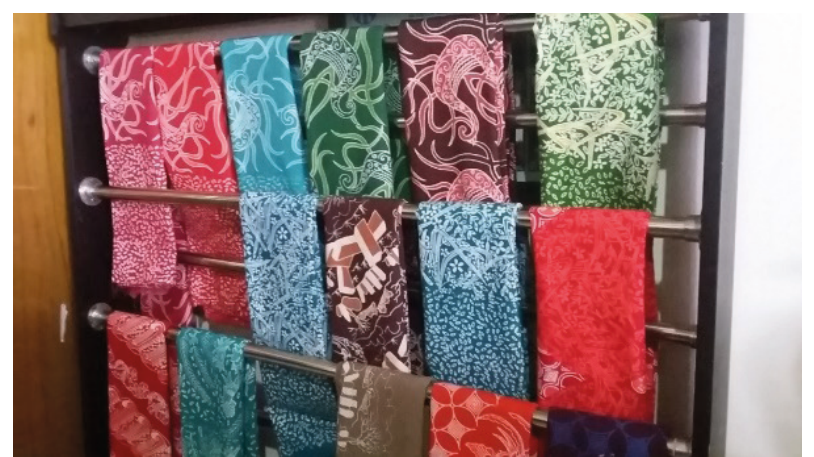

Gambar 5. Beberapa hasil Kriya Nusantara pengembangan motif batik Cianjur di LPK Nusa. (Sumber: dokumentasi penelitian, 2018)
Lembaga Pendidikan dan Keterampilan Nusa. LPK Nusa ini memberikan pelatihan batik kepada remaja yang putus sekolah. Adapun tujuannya ialah membantu pemerintah untuk memberikan pelatihan kepada remaja yang putus sekolah sehingga memiliki keterampilan dan bisa menggunakan keterampilan tersebut untuk bekerja dan memberikan peluang kerja bagi masyarakat luas, selain itu juga untuk melestarikan kearifan lokal yang ada dalam hal ini ialah batik Cianjur sebagai media komunikasi visual menyampaikan pesan-pesan atau nilainilai luhur melalu motif batiknya.

\section{Faktor Pendukung dan Penghambat Pedagogi Estetik melalui Batik Cianjur}

Ada beberapa faktor yang mempengaruhi proses pedagogi estetik melalui batik Cianjur, yang dibagi menjadi faktor pendukung dan faktor penghambat.

Faktor pendukung dari pelaksanaan proses pedagogi estetik melalui batik cianjur ialah adanya dukungan dari Pemerintah Kabupaten Cianjur serta Dinas Pendidikan yang menaungi lembaga pendidikan formal dan lembaga pendidikan non formal dalam melestarikan budaya, salah satunya melalui pelaksanaan proses pedagogi estetik melalui batik Cianjur.

Adanya lembaga atau institusi, merupakan sistem bentuk hubungan kesatuan masyarakat yang diatur oleh suatu budaya tertentu. Lembaga budaya yang terkait merupakan lembaga budaya yang berperan sebagai pendukung atau sponsor, baik itu lembaga pemerintah, lembaga swasta, dan lembaga pendidikan. Lembaga-lembaga tersebut memiliki peran yang besar dalam melindungi dan mengayomi terhadap seni budaya bangsa. Begitupun pada industri kecil atau seni kerajinan memerlukan perhatian penuh dari lembaga budaya. Daerah Cianjur sendiri terdapat lembaga-lembaga budaya yang membantu proses pedagogi estetik melalui batik Cianjur diantaranya LP3EM (Lembaga Pengkajian Pengembangan Pemberdayaan Ekonomi Masyarakat) Hibar Indonesia yang bergerak dalam mengembangkan potensi yang terdapat dimasyarakat yang bertujuan 
menggerakan ekonomi salah satunya melalui batik Cianjur. Kemudian terdapat Koperasi Batik Beasan Cianjur yang bergerak dalam bidang penjualan batik dan memperkenalkan kain batik kepada masyarakat yang bergerakannnya dibantu oleh lembaga Baleniaga Cianjur yang bergerak dalam bidang publikasi terhadap kegiatan UMKM yang ada di Cianjur.

Selain dari dukungan pemerintah Kabupaten Cianjur, Dinas Pendidikan Kabupaten Cianjur dan Lembaga Budaya, faktor pendukung lainnya ialah keanekaragaman potensi alam yang dimiliki oleh Kabupaten Cianjur yang dilengkapi dengan filosofi mendasar yang dipegang erat masyarakat Cianjur yaitu Ngaos (mengaji), Mamaos (kehalusan budi dan rasa), Maenpo (seni bela diri), Tatanen

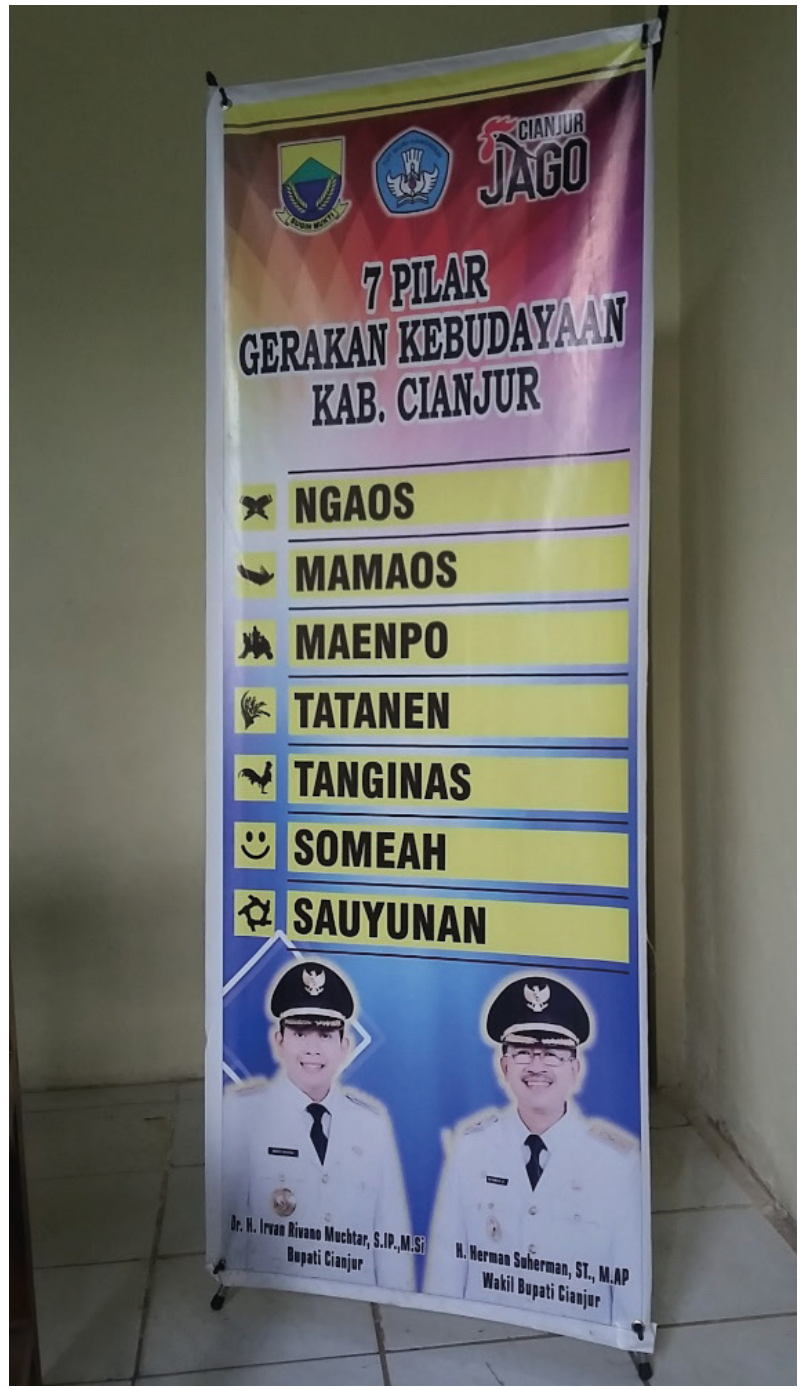

Gambar 6. 7 Pilar Gerakan Kebudayaan Kabupaten Cianjur yang menjadi sumber nilai bagi pengembangan motif batik Cianjur.

(Sumber: dokumentasi penelitian, 2018) (pertanian), Tanginas (tangkas/ sigap), Someah (ramah), dan sauyunan (kerukunan) menjadikan sumber inspirasi bagi pengembangan motif batik Cianjur.

Faktor penghambat dari pelaksanaan proses pedagogi estetik melalui batik Cianjur ini ialah pengerjaan batik yang dirasa sulit, batik merupakan bentuk ekspresi seni yang membutuhkan banyak tahapan dalam proses pengerjaannya dimulai dari proses ngarengreng (menggambar desain batik), ngajidaran (menggambar pola atau batas), neruskeun (melanjutkan desain), ngabiron (menutup bidang dengan malam), ngawarna (mewarna kain yang telah dibatik, hingga ngalorod (menghilangkan malam dengan cara direbus di sebuah tungku), proses ini dikerjakan secara berulang-ulang dan penuh kesabaran sehingga remaja di Kabupaten Cianjur merasa kesulitan untuk mempelajarinya. Hal ini sesuai dengan kendala yang dihadapi baik di lembaga pendidikan formal maupun di lembaga pendidikan non formal. Berdasarkan hasil wawancara dengan salah seorang guru seni budaya di SMPN 1 Kabupaten Cianjur mengatakan bahwa: "beberapa waktu, siswa-siswi pernah diajarkan teknik membatik dalam mata pelajaran seni budaya, namun karena teknik yang digunakan terbilang sulit kemudian peralatan batik dan keamanan dalam mengerjakan dirasa kurang mendukung sehingga siswa-siswi susah untuk menyelesaikan latihan membatiknya”. Hal yang serupa juga disampaikan oleh pimpinan LPK Nusa yang mengatakan bahwa dari sekian banyak remaja yang mengikuti latihan pembuatan batik Cianjur hanya satu atau dua orang yang bertahan, karena

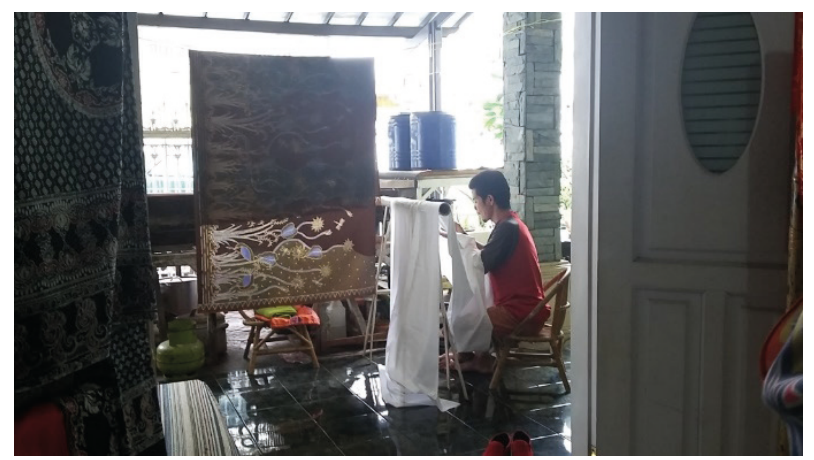

Gambar 7. Peserta didik lembaga pendidikan dan

Keterampilan Nusa yang konsisten melestarikan dan mengembangkan motif batik Cianjur.

(Sumber: dokumentasi penelitian, 2018) 
untuk membuat batik dibutuhkan ketekunan, keuletan, selain dari daya imajinasi dan kreasi yang tinggi.

\section{Upaya Mempertahankan Nilai Pedagogis dan Estetis Batik Cianjur}

Batik merupakan salah satu ekspresi kesenian tradisi yang semakin menapakkan jejak kebermaknaannya dalam khasanah kebudayaan Indonesia yang telah ada sejak berabad-abad lamanya yang terus hidup dan berkembang hingga kini. Sehingga dengan itu dikatakan bahwa batik merupakan salah satu bukti peninggalan sejarah budaya bangsa Indonesia. Seni batik juga merupakan suatu keahlian yang turun temurun. Seperti yang ditulis dalam buku Kerajinan Batik Indonesia oleh Sewan Susanto (1974: 15), menyatakan bahwa "Seni batik merupakan keahlian turun temurun yang sejak mulai tumbuh merupakan salah satu sumber kehidupan yang memberikan lapangan kerja yang cukup luas bagi masyarakat. Seni batik merupakan penyaluran kreasi yang mempunyai arti tersendiri, yang kadang-kadang dihubungkan dengan tradisi, kepercayaan dan sumber-sumber kehidupan yang berkembang di masyarakat.

Batik cianjur kembali diperkenalkan melalui karya kriya tekstil yang sederhana namun memiliki karakter yang menampilkan ciri khas kekuatan potensi daerah cianjur. Saat ini sudah banyak muncul beberapa motif-motif baru yang bersumber dari berbagai ide yang dilatarbelakngi oleh potensi alam dan budaya Cianjur. Untuk memperkaya khasanah motif di Cianjur pada tahun 2009 diadakan lomba rancang motif batik Cianjur yang diselenggarakan oleh Dinas Perindustrian dan Perdagangan Cianjur berkerjasama dengan Yayasan Batik Jawa Barat (YBJB) yang menghasilkan beberapa motif baru rancangan masyarakat Cianjur dan Jawa Barat.

Begitupun di lingkungan pendidikan Tahun 2013 diadakan lomba desain motif batik Cianjur yang menghasilkan tiga motif yaitu Gurisan, Kinanti, dan motif Pangkur di mana ketiga motif ini merupakan bagian dari batik Galuh Mukti khas Cianjur. Motif ini tersebut didesain oleh pelajar dari berbagai tingkat mulai dari SD sampai SMP dalam lomba desain batik hasil karya mereka dipergunakan oleh pelajar - pelajar Cianjur.

Pada Tahun 2017 Koperasi Batik Beasan Cianjur dan LP3EM Hibar Indonesia dalam rangka menyambut hari batik Nasional menyelenggarakan pemberian 2000 batik gratis (Batik Kinanti) khusus siswa kelas VII SMP/sederajat se-kabupaten Cianjur, hal ini bertujuan untuk memperkenalkan batik khas Cianjur kepada siswa- siswi pelajar guna menjaga dan melestarikan batik sebagai warisan dunia milik Bangsa Indonesia.

\section{Simpulan}

Batik Cianjur merupakan salah satu wujud budaya dalam bentuk kriya yang ada di Kabupaten Cianjur dengan kekhasan dan keunikan motif yang sesuai dengan keadaan alam dan kearifan lokal yang dimiliki yang sarat dengan nilai estetika dan pedagogis sehingga dapat dijadikan sebagai media pendidikan bagi masyarakat untuk lebih mengenal dan melestarikan batik Cianjur.

\section{Ucapan Terima Kasih}

Penulis mengucapkan terima kasih kepada Pemerintah Kabupaten Cianjur dan Dinas Pendidikan Kabupaten Cianjur yang telah memberikan izin serta meberikan data dan informasi terkait dengan penelitian yang dilakukan.

\section{Kepustakaan}

Kudiya, K. 2013. Batik Pesisir Selatan Jawa Barat, Yogyakarta : Jalasutra.

Anas, B. 2000. Refleksi Seni Rupa Indonesia Dulu, Kini, dan Esok. Jakarta: Balai Pustaka.

Panjaitan, L.M. dan Dadang Sundawa. 2016. Pelestarian Nilai-Nilai Civic Culture dalam Memperkuat Identitas Budaya Masyarakat: Makna Simbolik Ulos dalam Pelaksanaan Perkawinan Masyarakat Batak Toba di Sitorang. Journal of Urban Society's Arts, Vol. 3 No. 2, 64-72.

Sadulloh, U. dkk. 2010. Pedagogi: Ilmu Mendidik. Bandung: Alfabeta.

Sauri, S. dan Herlan Firmansyah. 2010. Meretas 
Pendidikan Nilai. Bandung: Arfino Raya. Sumardjo, J. 2000. Filsafat Seni. Bandung: Penerbit ITB.

Susanto, S. 1974. Seni Kerajinan Batik Indonesia. Yogyakarta: Balai Penelitian Batik dan Kerajinan, Lembaga Penelitian dan Pendidikan
Industri, Dep. Perindustrian RI.

Tampubolon, A. dan Cecep Darmawan. 2016. Fashion Budaya Nasional dalam Konteks Wawasan Kebangsaan: Studi Kasus pada Jember Fashion Carnaval. Journal of Urban Society's Arts, Vol. 3 No. 1, 19-26. 